Orientador: Carlos Alberto Alvaro de Oliveira

A tese identifica, ao longo da histónia do direito processual civil, três modelos possiveis de distribuição das posições jurídicas entre o juiz e as partes: o modelo isonômico, o modelo assimétrico e o modelo cooperativo. Semelhantes modelos são pensados a partir de pressupostos sociais, lógicos e éticos. Nada obstante de tipo ideal, a tese não se furta de apontar exemplos concretos de processos isonốmicos (o processo grego antigo e o processo do ordo iudiciarius medieval italiano do século XIV) e de processos assimétricos (o processo da cognitio extra ordinem romano e o processo prussiano moderno do século XVIII). A tese está em que o processo civil cooperativo é o processo do Estado Constitucional. No processo civil pautado pela colaboração, o juiz tem deveres de diálogo, auxilio, prevenção e esclarecimento para com as partes. A tese busca explicitar esses deveres judiciais tomando como base o formalismo do procedimento comum ordinário brasileiro, analisando-o a partir das fases postulatória, de saneamento, instrutória, decisória e recursal.

A banca examinadora foi composta pelos Professores: Adroaldo Furtado Fabricio, Professor da Universidade Federal do Rio Grande do Sul e Doutor em Direito pela mesma instituição; Fredie Souza Didier Junior, Professor da Universidade Fedefal da Bahia e Doutor em Direito pela Pontificia Universidade Católica de São Paulo; José Maria Rosa Tesheiner, Professor da Pontificia Universidade Católica do Rio Grande do Sul e Doutor em Direito pela mesma universidade; José Rogério Cruz e Tucci, Professor da Universidade de São Paulo e Doutor em Direito pela Universitá di Roma, UR, Itália; Ovidio Araújo Baptista da Silva, Professor da Universidade Federal do Rio Grande do Sul e Doutor em Direito pela mesma instituição.

\title{
O Princípio da Diferença e o Kantismo na Teoria da Justiça de John Rawls
}

Por Voltaire de Freitas Michel

Data da defesa da tese: 30/11/2007

Orientador: Luís Fernando Barzotto

A tese trata de dois temas importantes no interior da Teoria da Justiça de John Rawls: de um lado, o principio da diferença, entendido como o critério que o filosofo reputa válido para a distribuição das desigualdades numa sociedade; de outro, as suas alegadas raízes kantianas, como Rawls expressamente reconhece em seu livro de 1971. Na tese, o 
autor sustenta que estas duas idéias principais na Teoria da Justiça são incompativeis, embora tenham surgido, para Rawis, num mesmo momento da evoluçăo de seu pensamento.

A banca foi composta pelos Professores Doutores: Luis Fernando Barzotto, Professor da Universidade Federal do Rio Grande do Sul e Doutor em Direito pela Universidade de Sấo Paulo que, na oportunidade, presidiu a banca; José Alcebíades de Oliveira Júnior, Professor da Universidade Federal do Rio Grande do Sul e Doutor em Direito pela Universidade Federal de Santa Catarina; José Nedel, Professor da Universidade do Vale do Rio dos Sinos e Doutor em Filosofia pela Pontificia Universidade Católica do Rio Grande do Sul; Álvaro de Vita, Professor da Universidade de São Paulo e Doutor em Ciência Política pela Universidade de São Paulo; Rodrigo Valin de Oliveira, Professor da Escola Superior da Magistratura Federal do Rio Grande do Sul e Doutor $\mathrm{em}$ Direito pela Universidade de São Paulo. A referida tese foi orientada pelo Professor Cláudio Fortunato Michelon Junior, e a defesa presidida pelo Professor Luís Fernando Barzotto.

\section{Insolvência Internacional no Mercosul - Uma Proposta de Regulamentação}

\section{Por Silvio Javier Battello Calderon}

Data da defesa da tese: 18/12/2007

Orientadora: Cláudia Lima Marques

Esta pesquisa trata dos processos judiciais de insolvência iniciados contra empresa que pratique atividades ou que possua bens, créditos ou débitos em mais de um Estado-membro do Mercosul. A investigação parte da análise da internacionalizaçăo da atividade empresarial, passando pela competência internacional, regras de direito aplicável, atividades dos órgãos concursais, e cooperação jurisdicional internacional, culminando com a proposição de uma nova regulamentação sobre a matéria para o âmbito regional.

A banca foi composta pelos Professores Doutores: Carlos Klein Zanini, Professor da Universidade Federal do Rio Grande do Sul e Doutor em Direito pela Universidade de São Paulo; Gerson Luiz Carlos Branco, Professor da Universidade Luterana do Brasil e Doutor em Direito pela Universidade Federal do Rio Grande do Sul; Peter Walter Ashton, Professor da Pontifícia Universidade Católica do Rio Grande do Sul e Doutor em Direito pela Universidade Federal do Rio Grande do Sul; Luiz Otavio Pimentel, Professor da Universidade Federal de Santa 